\title{
Blasting design and drawbell implementation at the Chuquicamata Underground mine
}

\author{
F Rodríguez CODELCO, Chile
}

A Berg CODELCO, Chile

JC Videla CODELCO, Chile

$\mathrm{N}$ Jamett CODELCO, Chile

D Morales ENAEX, Chile

R Castro University of Chile, Chile

L Arancibia BCTEC Engineering and Technology, Chile

\begin{abstract}
In caving operations, the blasting of drawbells is critical for starting production from drawpoints. The trend in the industry is to blast drawbells in a single phase to avoid exposing personnel to the front and to increase the rate at which drawpoints can be incorporated into production. A review of the current state of the art suggests there is no consensus on how to design a single-phase drawbell blast (SPDB). The Chuquicamata Underground Mine (MCHS) implemented an SPDB using emulsions as the explosive. Before implementation, trials were performed showing good results in relation to fragmentation and final drawbell geometry. The design was implemented at production scale allowing more than 8 drawbells to be incorporated per month. Based on the positive results, guidelines to blast drawbells in a single phase were established and are described in this article.
\end{abstract}

\section{Introduction}

Chuquicamata Underground Mine (MCHS) is operated by Codelco, and is located $15 \mathrm{~km}$ north of Calama, Chile. The mine transitioned from a century-old open pit operation to an underground mine using the Macro-Block Caving Method to extract deep reserves and prolong the life of the mine for at least another 50 years. This method represents the best alternative to exploit a massive and low-grade mineralized orebody because of its higher production and lower costs in comparison to other underground methods (Araneda 2015).

Blasting design for drawbell implementation will be an important stage in developing MCHS. Indeed, at level Lift 1 alone, there will be over 1,000 drawbells, and this is only one of the three levels to be built. Thus far, MCHS has used emulsion as its main explosive because the experience with this product has been positive as faster development, less overexcavation and increased safety (Alcaíno 2018; Paredes et al. 2019).

The blast design criteria for drawbells in caving mines are mainly based on empirical rules and operational experience. Drawbell design in Block/Panel Caving has undergone changes in geometry and in the way drawbells are created. For example, drawbell design was implemented by blasting in 2 or 3 phases, using ANFO as an explosive, between 1985 and 1994 at "Teniente 4 Sur". This design was implemented to address requirements such as changes in direction of access or in the direction of the extraction drift, modifications in drawpoint location, and the connection between two different mining methods and/or mine boundaries (Jofre et al. 2000). 
Efforts have been made in recent years to establish the drawbell blast in a single phase to increase productivity and eliminate the risk of exposing employees to broken rock during the loading activity (Altamirano 2014). In 2003, Lovitt \& Degay studied drawbell blasting in a single phase using electronic detonators at Freeport in Indonesia. Silveira et al. (2005) conducted a study of the change in the production design of Lift \#2 (second production level) in Northparkes, establishing drawbell blasting in a single phase using emulsion as the main explosive. Music \& San Martin (2010) published results of the implementation of a drawbell blast in a single phase at the El Teniente mine, where this option was adopted to increase drilling and blasting performance. To complete the blasting of a 4,300 $\mathrm{m}^{3}$ drawbell in that study, they used emulsion explosive with delay times between 20 and 30 ms between holes, a raise diameter for the free face of $1.5 \mathrm{~m}$, and a powder factor twice as high as that used for a drawbell blast in multiple phases.

In a later study, Dunstan \& Popa (2012) summarized their experience establishing drawbells at Ridgeway Deeps and Cadia East operations. In the Ridgeway case, 133 drawbells were blasted using 14 different designs, all with the blast in single phase. In the Cadia East case, a circular drawbell blast design was made using 7 empty holes of $200 \mathrm{~mm}$ diameter as a free face and 136 drillholes of $76 \mathrm{~mm}$ diameter for the explosive; this methodology allowed 2,100 $\mathrm{m}^{3}$ drawbells to be blasted in single phase.

A review of the literature reveals general rules about building a drawbell in one blast phase. However, an engineering design methodology for single-phase drawbell blasting has yet to be established. Here a methodology and the mine-scale implementation of a single-phase drawbell blast design are presented that was successfully used at the Chuquicamata Underground Mine.

\section{$2 \quad$ Methodology}

A methodology using a series of steps was established to define a drawbell blasting design as shown in Figure 1.

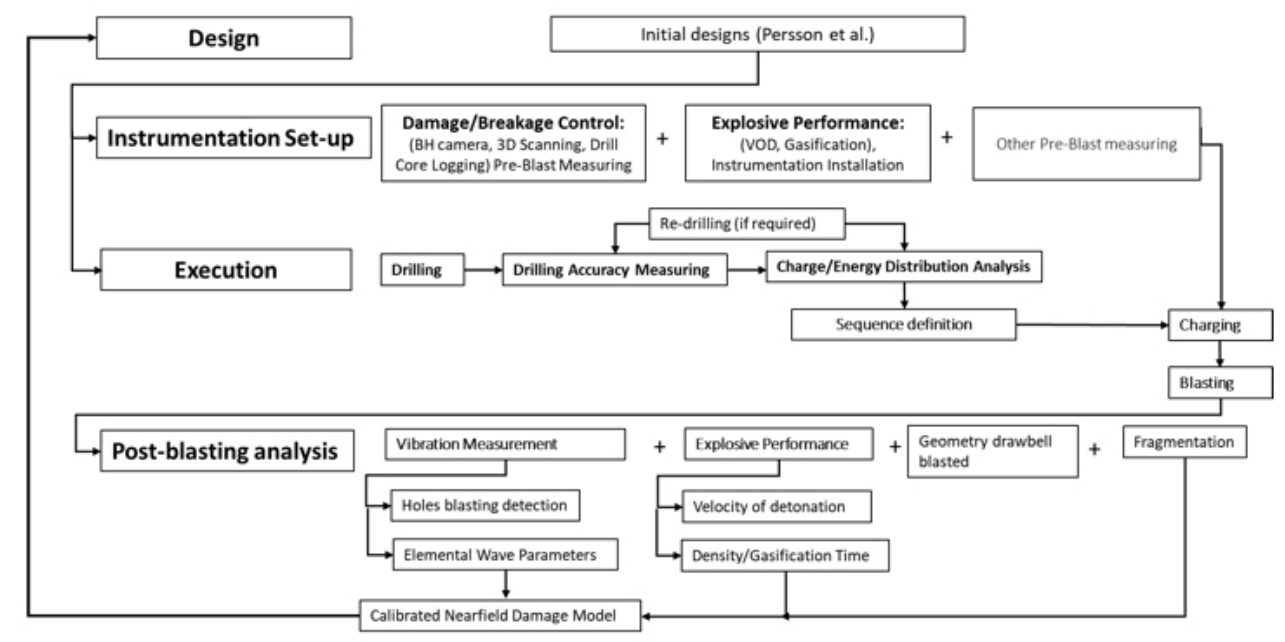

Figure 1 Drawbell blasting design methodology

In a first stage, two designs based on the methodology of Persson et al. (1994) were proposed. Then, a series of instruments to measure the results of the designs were used. The designs were tested, and results analysed to select one to be implemented in the mine based on fragmentation and geometry generated by the blasting. Once the design was implemented, the results were analysed to identify improvement opportunities.

\section{Equipment and emulsions}

A drilling and blasting strategy for the drawbell is detailed below. 


\subsection{Drilling}

The drilling was carried out by a Sandvik DL421TC equipment (see Figure 2) with the positioning and drill hole dip made using a manual system. The hole deviations were quantified using a Boretrak deviation measurement system (Enaex 2018a). The deviation of drillholes allowed field data to inform blast analysis and simulations prior to the stage of charging with explosives.

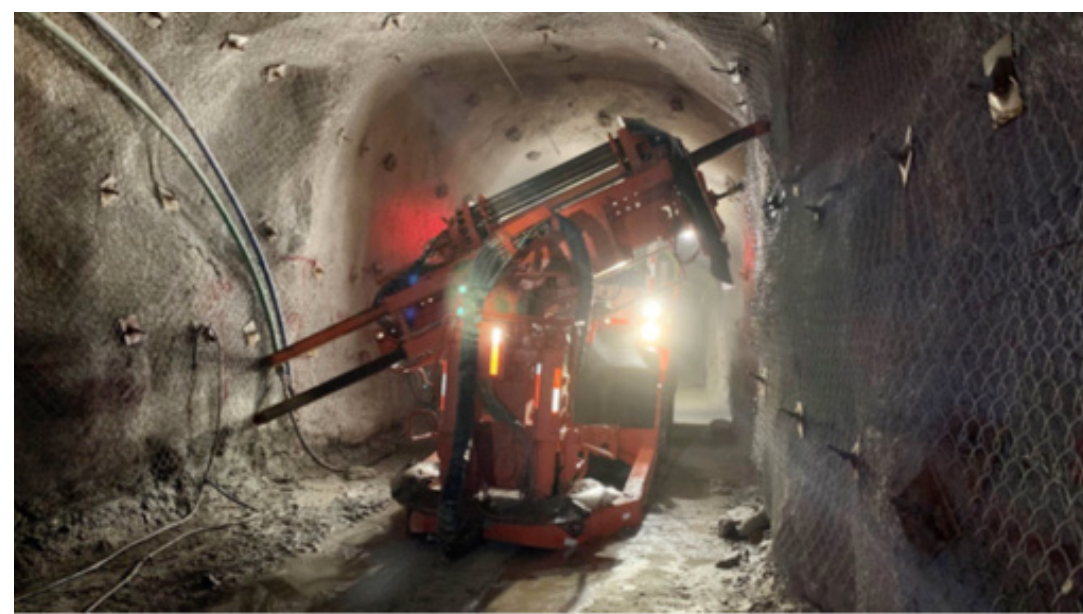

Figure 2 Drilling with Sandvik DL421TC

Energy distribution simulations of the implemented drill design were conducted to analyze the blasting performance previous to the charging activity. Figure 3 shows an example of a blasting simulation with the actual holes, in red shows the zone with high damage.
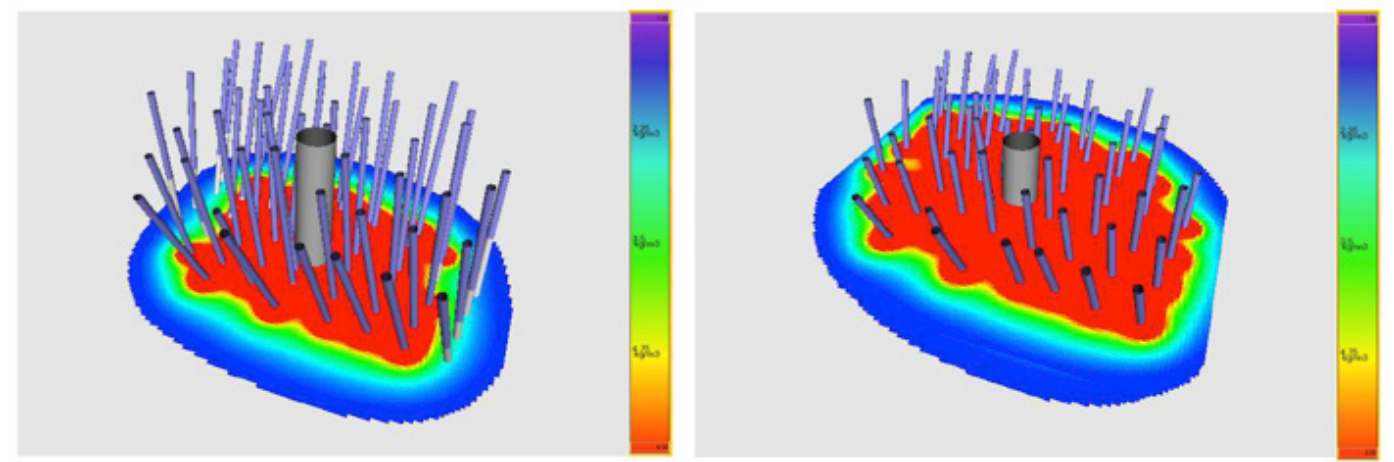

\section{Figure 3 Simulation of blasting with real holes}

\subsection{Blasting}

The explosive was charged with a mechanized equipment using pumpable gasified emulsion (Duoblast- $V$, Enaex), which has high strength, good adherence and high velocity of detonation (VOD). The main technical characteristics of the gasified pumpable emulsion are shown in Table 1.

Table 1 Technical characteristics gasified pumpable emulsion (Duoblast-V Enaex 2018b)

\begin{tabular}{|c|c|}
\hline Parameter & Value \\
\hline Density $(\mathrm{g} / \mathrm{mL})$ & $1.15 \pm 5 \%$ \\
\hline Velocity of detonation $(\mathrm{m} / \mathrm{s})$ & $4,000-5,000$ \\
\hline Detonation pressure $(\mathrm{MPa})$ & 6,000 \\
\hline Energy $(\mathrm{KJ} / \mathrm{Kg})$ & 2,736 \\
\hline Volume of gases $(\mathrm{L} / \mathrm{Kg})$ & 1,000 \\
\hline Critical diameter $(\mathrm{m})$ & 0.038 \\
\hline Resistance to water & Good \\
\hline
\end{tabular}


The sensitization was carried out in-situ by a gassing process. Through this process the condition of the explosive agent was obtained. The charging was then performed through UBS (bulking emulsions system for upholes) equipment units (see Figure 4).

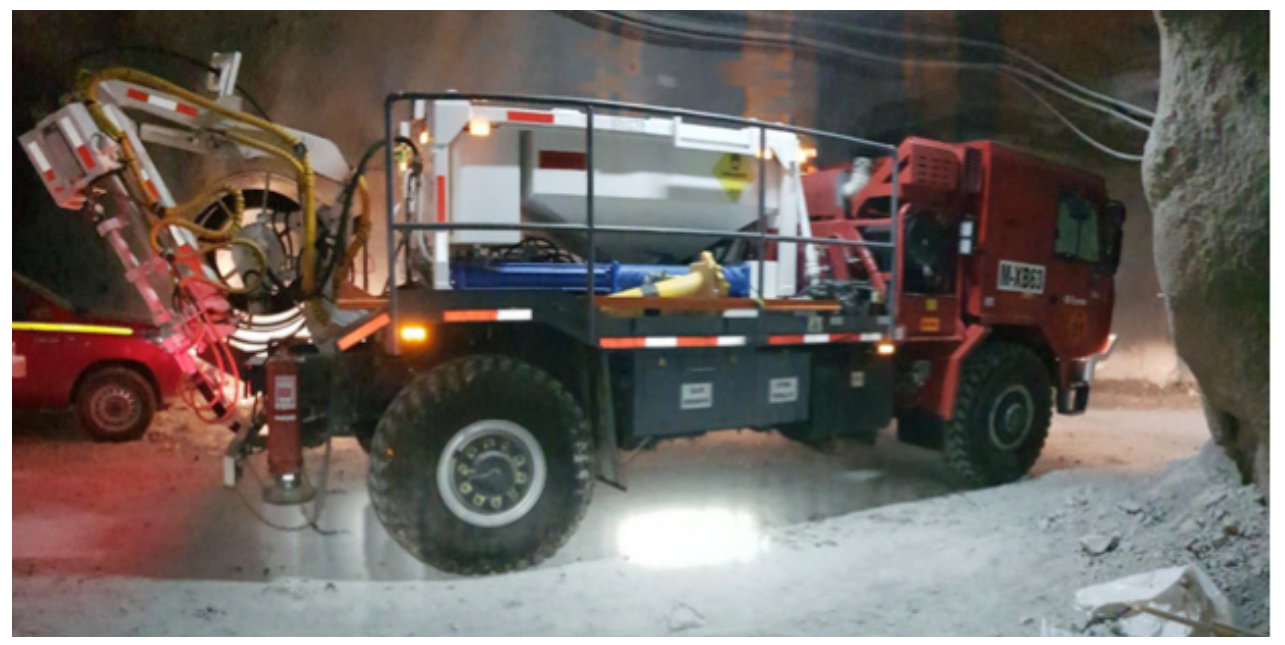

Figure 4 UBS mobile ENAEX equipment used for charging pumpable emulsion on the undercut level

\section{$4 \quad$ Initial tests}

The Chuquicamata Underground Mine (MCHS) conducted an industrial drawbell blast test in a single phase using emulsion as the main explosive (Paredes et al. 2019). Two tests were conducted with different blasting designs and rock types. Figure 5 shows the location of the drawbell tests.

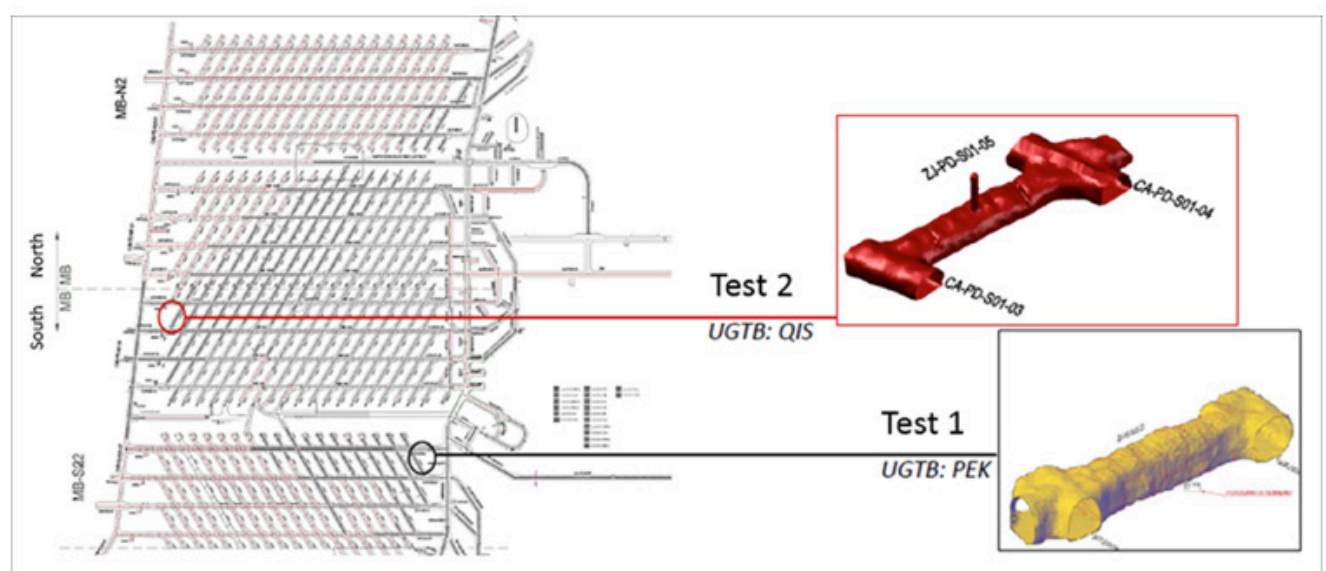

Figure 5 Location of drawbells tests in the Chuquicamata Underground Mine (Paredes et al. 2019)

The blast design of the first drawbell (Test 1) included sixty boreholes of $76.2 \mathrm{~mm}$ of diameter distributed in 9 rings with a $1.5 \mathrm{~m}$ slot raise. Table 2 shows the main parameters associated with the Drawbell 1 blasting design, whereas Figure 6 shows the location of the boreholes. 


\section{Table 2 First drawbell - blast design parameters (Test 1)}

\begin{tabular}{|c|c|}
\hline Parameter & Value \\
\hline Drawbell volume $\left(\mathrm{m}^{3}\right)$ & 1,181 \\
\hline Drawbell height $(\mathrm{m})$ & 9 \\
\hline Slot raise diameter $(\mathrm{m})$ & 1.5 \\
\hline Hole diameter $(\mathrm{mm})$ & 76.2 \\
\hline Spacing $(\mathrm{m})$ & $1.7-2.4$ \\
\hline Burden $(\mathrm{m})$ & 1.9 \\
\hline \# holes & 60 \\
\hline Drilling meters $(\mathrm{m})$ & 569 \\
\hline Drilling factor $\left(\mathrm{m} / \mathrm{m}^{3}\right)$ & 0.63 \\
\hline Powder factor $\left(\mathrm{kg} / \mathrm{m}^{3}\right)$ & 2.66 \\
\hline Powder factor $(\mathrm{kg} / \mathrm{ton})$ & 1.05 \\
\hline
\end{tabular}

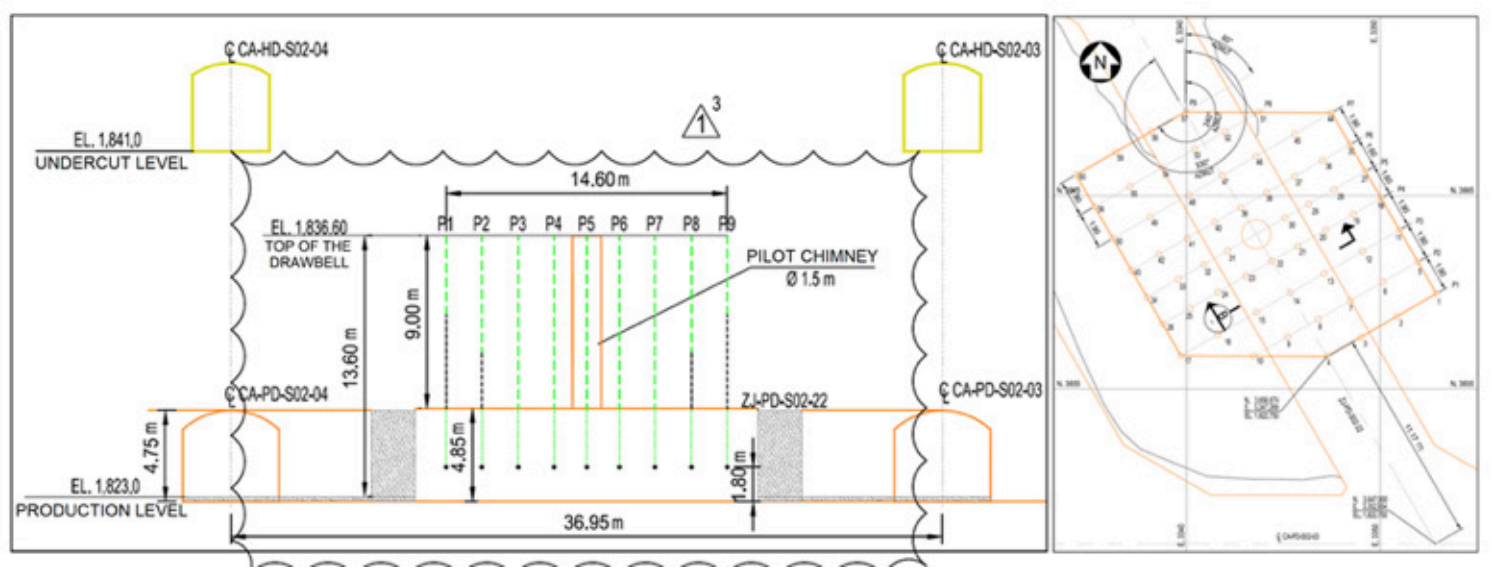

\section{Figure 6 Drawbell 1 design section and plan view (Test 1)}

The blast design of the second drawbell (Test 2) included 48 boreholes distributed in 9 rings with a $1.5 \mathrm{~m}$ slot raise. Table 3 shows the main parameters associated with the Drawbell 2 blasting design, and Figure 7 shows the location of drill holes.

Table 3 Design parameters Drawbell 2 (Test 2)

\begin{tabular}{|c|c|}
\hline Parameter & Value \\
\hline Drawbell volume $\left(\mathrm{m}^{3}\right)$ & 1,181 \\
\hline Drawbell height $(\mathrm{m})$ & 9 \\
\hline Slot raise diameter $(\mathrm{m})$ & 1.5 \\
\hline Hole diameter $(\mathrm{mm})$ & 76.2 \\
\hline Spacing $(\mathrm{m})$ & $2.5-2.6$ \\
\hline Burden $(\mathrm{m})$ & $1.6-1.8$ \\
\hline \# holes & 48 \\
\hline Drilling meters $(\mathrm{m})$ & 466 \\
\hline Drilling factor $\left(\mathrm{m} / \mathrm{m}^{3}\right)$ & 0.51 \\
\hline Powder factor $\left(\mathrm{kg} / \mathrm{m}^{3}\right)$ & 2.0 \\
\hline Powder factor $(\mathrm{kg} / \mathrm{ton})$ & 0.88 \\
\hline
\end{tabular}



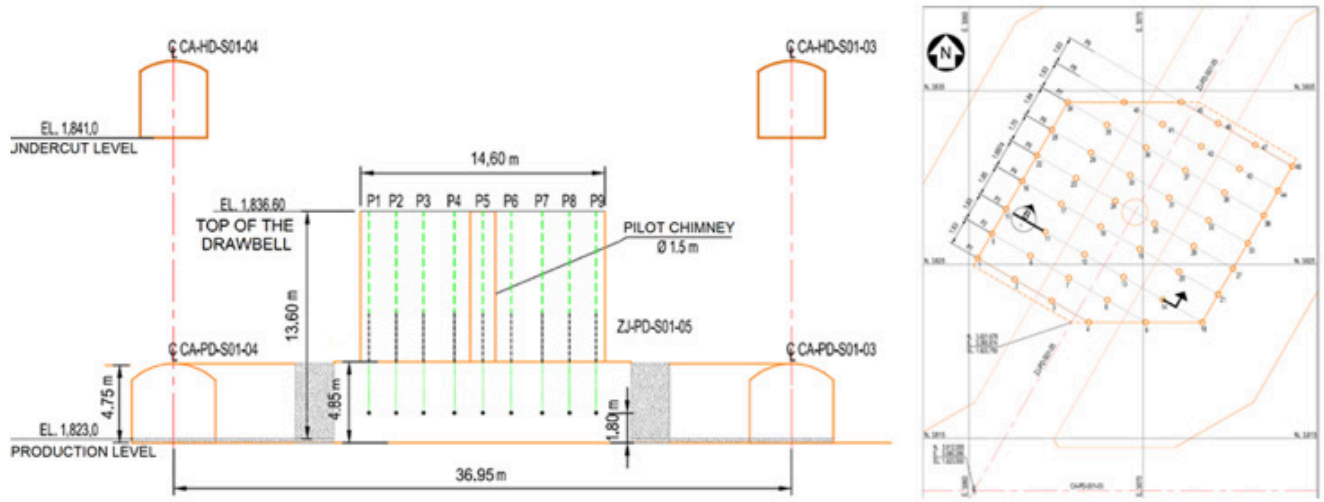

Figure 7 Drill holes distribution and design Drawbell 2 (Test 2)

\subsection{Results of initial tests}

The initial test results were detailed by Paredes et al. (2019). A comparative analysis was performed and is described below.

The decrease in the number of holes used in Test 2 represented a reduction of $19 \%$ in explosive consumption when compared to Test 1, which resulted in a decrease in the powder factor from $2.66 \mathrm{~kg} / \mathrm{m}^{3}$ to $2.10 \mathrm{~kg} /$ $\mathrm{m}^{3}$. Similarly, a 38-minute decrease in the charging process (15\% less) from Test 1 to Test 2 was recorded.

In relation to the result of the blast in Test 1, Figure 8 shows a muckpile with homogeneous granulometry, where the maximum size does not exceed $803 \mathrm{~mm}$ and the $\mathrm{d} 80$ is between $307 \mathrm{~mm}$ and $325 \mathrm{~mm}$. The fragmentation was estimated based on photographic record obtained considering that a reference measure (length of $1 \mathrm{~m}$ ) was inserted.

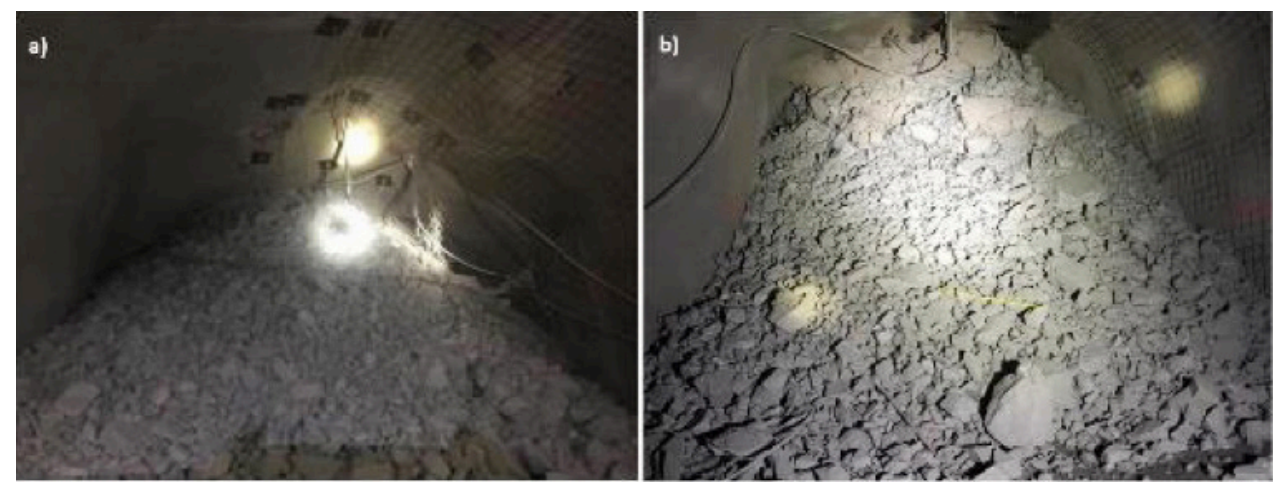

Figure 8 Post-blast results a) from drive 4 b) from drive 3

Test 2 shows a coarser fragmentation than in Test 1, but it could easily be handled by the load system. No significant damage to infrastructure was observed (see Figure 9).
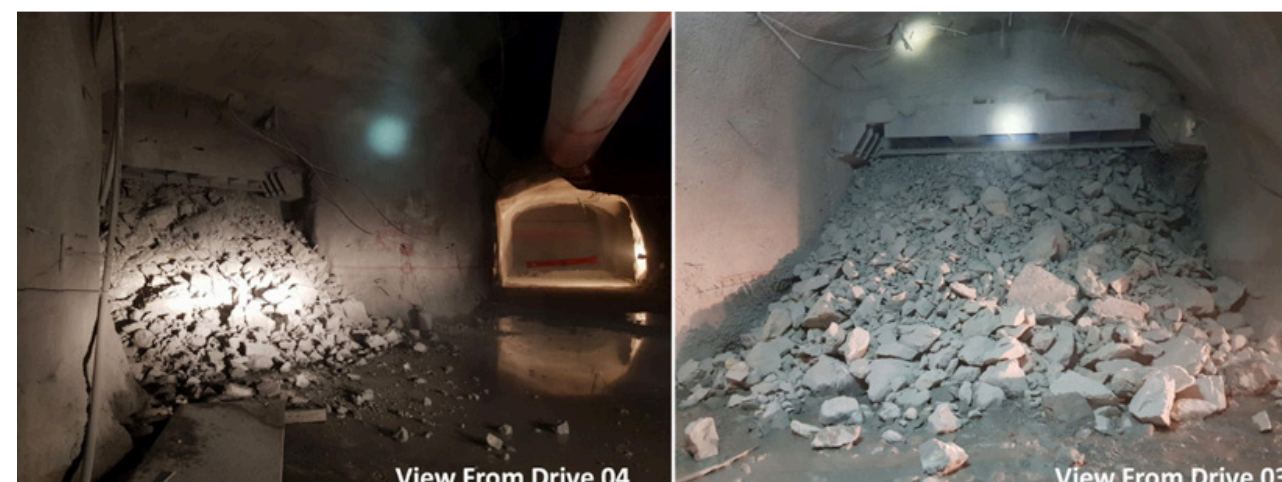

Figure 9 Blasted material pile in drives 3 and 4. Drawbell 2 
VOD measurements ranged from 4,446 - 4,501 m/s in Test 1 and from 4,153-4,627 m/s in Test 2, implying that both tests featured velocity of detonation values within the expected ranges.

Figure 10 shows the resulting geometry of Test 1 . In general terms, the drawbell geometry evidenced only minimal damage on the perimeter, which was expected from the design phase. Finally, the pre and post bore-hole camera inspection of damage control holes indicated there was no observable damage in the brow pillar.

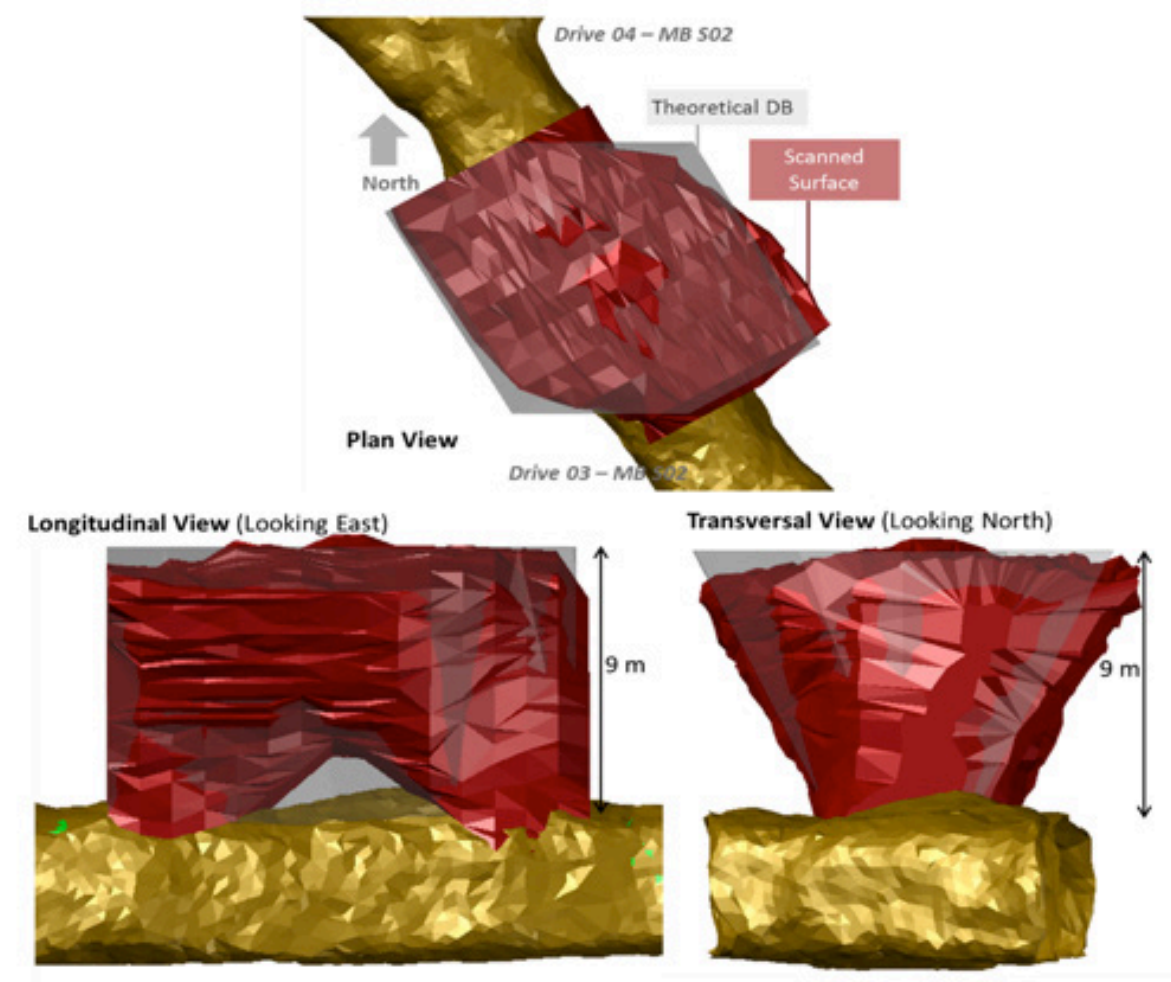

Figure 10 Scanned Surface and Theoretical Drawbell (Paredes et al. 2019)

Both designs produced a good result in terms of fragmentation and low damage to the infrastructure.

\section{$5 \quad$ Production blast drawbell}

Following these trials, Chuquicamata Underground Mine adopted the design of Test 1 for most of the drawbell blasting, i.e. with close to 60 holes. Only 2 drawbells were blasted with a 45-hole design and 48 holes; these two drawbells are half-drawbells with only one drawpoint. The decision was based on ensuring a finer fragmentation and correct excavation of the drawbell.

Table 4 summarizes the drawbell blasts performed, sorted by date, from 31-03-2019 to 07-10-2019. The drawbells located on drive 1 of MB-S01 correspond to half-drawbells. Figure 11 is shown in red with the drawbells incorporated. 
Table 4 Summary of blast data in Underground Chuquicamata Mine

\begin{tabular}{|c|c|c|c|c|c|c|c|c|c|}
\hline Drawbell & Location & $\begin{array}{c}\text { No } \\
\text { holes }\end{array}$ & $\begin{array}{l}\text { Planned } \\
\text { drilling } \\
\text { (m) }\end{array}$ & $\begin{array}{l}\text { Actual } \\
\text { drilling } \\
\text { (m) }\end{array}$ & Compliance & $\begin{array}{l}\text { Meters } \\
\text { charged } \\
\text { (m) }\end{array}$ & $\begin{array}{l}\text { Explosive } \\
\text { used }(\mathrm{kg})\end{array}$ & $\begin{array}{l}\text { Volume } \\
\text { to } \\
\text { remove } \\
\left(\mathrm{m}^{3}\right)\end{array}$ & $\begin{array}{l}\text { Powder } \\
\text { factor } \\
\left(\mathrm{kg} / \mathrm{m}^{3}\right)\end{array}$ \\
\hline $\begin{array}{l}\text { ZJ08S-C1 } \\
- \text { MBS01-001 }\end{array}$ & $\begin{array}{l}\text { MB-S01, drive 1; } \\
\text { drawpoint drift } 08\end{array}$ & 45 & 472.6 & 474.2 & $100 \%$ & 372.2 & 1,937 & 720 & 2.69 \\
\hline $\begin{array}{l}\text { ZJ07-C1-2- } \\
\text { MBS01-002 }\end{array}$ & $\begin{array}{l}\text { MB-S01, between } \\
\text { drives } 1 \text { and } 2 ; \\
\text { drawpoint drift } 07\end{array}$ & 62 & 603.9 & 579.7 & $96 \%$ & 429.5 & 2,254 & 917 & 2.46 \\
\hline $\begin{array}{c}\text { ZJ09S-C1 } \\
\text {-MBS01-003 }\end{array}$ & $\begin{array}{l}\text { MB-S01, drive 1; } \\
\text { drawpoint drift } 09\end{array}$ & 48 & 442.0 & 439.7 & $99 \%$ & 341.0 & 1,752 & 720 & 2.43 \\
\hline $\begin{array}{l}\text { ZJ06-C2-3- } \\
\text { MBS01-004 }\end{array}$ & $\begin{array}{l}\text { MB-S01, drives } 2 \\
\text { and 3; drawpoint } \\
\text { drift } 06\end{array}$ & 61 & 597.2 & 589.1 & $99 \%$ & 425.7 & 2,233 & 917 & 2.44 \\
\hline $\begin{array}{l}\text { ZJ08-C1-2- } \\
\text { MBS01-011 }\end{array}$ & $\begin{array}{l}\text { MB-S01, between } \\
\text { drives } 1 \text { and } 2 ; \\
\text { drawpoint drift } 08\end{array}$ & 61 & $S / I$ & 578.8 & - & 420.8 & 2,212 & 917 & 2.41 \\
\hline $\begin{array}{l}\text { ZJ07-C-2-3- } \\
\text { MBS01-017 }\end{array}$ & $\begin{array}{l}\text { MB-S01, between } \\
\text { drives } 2 \text { and 3; } \\
\text { drawpoint drift } 07\end{array}$ & 61 & 545.9 & $S / I$ & - & 385.9 & 2,021 & 917 & 2.20 \\
\hline $\begin{array}{l}\text { ZJ10S-C-1- } \\
\text { MBS01-023 }\end{array}$ & $\begin{array}{l}\text { MB-S01, drive 1; } \\
\text { drawpoint drift } 10\end{array}$ & 67 & 434.9 & 403.0 & $93 \%$ & 279.0 & 1,461 & 730 & 2.00 \\
\hline $\begin{array}{l}\text { ZJ09-C-1-2- } \\
\text { MBS01-024 }\end{array}$ & $\begin{array}{l}\text { MB-S01, between } \\
\text { drives } 1 \text { and 2; } \\
\text { drawpoint drift } 09\end{array}$ & 63 & 618.9 & 598.7 & $97 \%$ & 431.7 & 2,272 & 917 & 2.48 \\
\hline $\begin{array}{l}\text { ZJ10-C1-2- } \\
\text { MBS01-028 }\end{array}$ & $\begin{array}{l}\text { MB-S01, between } \\
\text { drives } 1 \text { and } 2 ; \\
\text { drawpoint drift } 10\end{array}$ & 60 & 440.7 & 429.8 & $98 \%$ & 314.8 & 1,648 & 917 & 1.80 \\
\hline $\begin{array}{l}\text { ZJ11S-C-01- } \\
\text { MBS01-031 }\end{array}$ & $\begin{array}{l}\text { MB-S01, drive 1; } \\
\text { drawpoint drift } 11\end{array}$ & 61 & 450.2 & 369.9 & $82 \%$ & 276.9 & 1,450 & 730 & 1.99 \\
\hline $\begin{array}{l}\text { ZJ08-C2-3- } \\
\text { MBS01-035 }\end{array}$ & $\begin{array}{l}\text { MB-S01, between } \\
\text { drives } 2 \text { and 3; } \\
\text { drawpoint drift } 08\end{array}$ & 59 & 436.4 & 420.1 & $96 \%$ & 307.1 & 1,613 & 917 & 1.76 \\
\hline $\begin{array}{l}\text { ZJ06-C-3-4- } \\
\text { MBS01-038 }\end{array}$ & $\begin{array}{l}\text { MB-S01, between } \\
\text { drives } 3 \text { and } 4 ; \\
\text { drawpoint drift } 06\end{array}$ & 60 & 580.1 & 544.6 & $94 \%$ & 376.6 & 1,970 & 917 & 2.15 \\
\hline $\begin{array}{l}\text { ZJ07-C3-4- } \\
\text { MBS01 }\end{array}$ & $\begin{array}{l}\text { MB-S01, between } \\
\text { drives } 3 \text { and 4; } \\
\text { drawpoint drift } 07\end{array}$ & 62 & 580.9 & 537.7 & $93 \%$ & 383.7 & 2,741 & 2,197 & 1.25 \\
\hline $\begin{array}{l}\text { ZJ03-C1S-2N } \\
\text { MBS01 }\end{array}$ & $\begin{array}{l}\text { MB-S01, between } \\
\text { drives } 1 \text { and } 2 ; \\
\text { drawpoint drift } 03\end{array}$ & 59 & 570.7 & 663 & $116 \%$ & 508.0 & 3,626 & 2,197 & 1.65 \\
\hline
\end{tabular}


Table 4 Summary of blast data in Underground Chuquicamata Mine (continued)

\begin{tabular}{|c|c|c|c|c|c|c|c|c|c|}
\hline Drawbell & Location & $\begin{array}{l}\text { No } \\
\text { holes }\end{array}$ & $\begin{array}{l}\text { Planned } \\
\text { drilling } \\
\text { (m) }\end{array}$ & $\begin{array}{l}\text { Actual } \\
\text { drilling } \\
\text { (m) }\end{array}$ & Compliance & $\begin{array}{l}\text { Meters } \\
\text { charged } \\
\text { (m) }\end{array}$ & $\begin{array}{l}\text { Explosive } \\
\text { used (kg) }\end{array}$ & $\begin{array}{l}\text { Volume } \\
\text { to } \\
\text { remove } \\
\left(\mathrm{m}^{3}\right)\end{array}$ & $\begin{array}{l}\text { Powder } \\
\text { factor } \\
\left(\mathrm{kg} / \mathrm{m}^{3}\right)\end{array}$ \\
\hline $\begin{array}{c}\text { ZJ05-C4S } \\
-1 \mathrm{~N}\end{array}$ & $\begin{array}{c}\text { Between drive } \\
4 \text { (MB-S01) and } \\
\text { drive } 1 \text { (MB-N01); } \\
\text { drawpoint drift } 05\end{array}$ & 63 & 574.4 & 540.8 & $94 \%$ & 387.8 & 2,772 & 2,197 & 1.26 \\
\hline $\begin{array}{l}\text { ZJ12-C1S- } \\
\text { MBS01 }\end{array}$ & $\begin{array}{l}\text { MB-S01, drive 1; } \\
\text { drawpoint drift } 12\end{array}$ & 58 & 439.7 & 470.2 & $107 \%$ & 381.2 & 2,486 & 2,197 & 1.13 \\
\hline $\begin{array}{l}\text { ZJ11-C-1-2- } \\
\text { MBS01 }\end{array}$ & $\begin{array}{l}\text { MB-S01, between } \\
\text { drives } 1 \text { and 2; } \\
\text { drawpoint drift } 11\end{array}$ & 60 & 433.6 & 446.2 & $103 \%$ & 326.2 & 1,687 & 917 & 1.84 \\
\hline $\begin{array}{l}\text { ZJ08-C-3- } \\
\text { 4-MBS01 }\end{array}$ & $\begin{array}{l}\text { MB-S01, between } \\
\text { drives } 3 \text { and 4; } \\
\text { drawpoint drift } 08\end{array}$ & 60 & 433.6 & 407.9 & $94 \%$ & 309.9 & 1,608 & 917 & 1.75 \\
\hline $\begin{array}{l}\text { ZJ06- } \\
\text { C4S-C1N- } \\
\text { MBS01- } \\
\text { MBN01 }\end{array}$ & $\begin{array}{c}\text { Between drive } \\
4 \text { (MB-S01) and } \\
\text { drive } 1 \text { (MB-N01); } \\
\text { drawpoint drift } 06\end{array}$ & 60 & 578.2 & 563.7 & $97 \%$ & 411.7 & 2,139 & 917 & 2.33 \\
\hline $\begin{array}{l}\text { ZJ07- } \\
\text { C4S-C1N- } \\
\text { MBS01- } \\
\text { MBN01 }\end{array}$ & $\begin{array}{l}\text { Between drive } \\
4 \text { (MB-S01) and } \\
\text { drive } 1 \text { (MB-N01); } \\
\text { drawpoint drift } 07\end{array}$ & 60 & 578.4 & 551.1 & $95 \%$ & 406.1 & 2,113 & 917 & 2.30 \\
\hline $\begin{array}{l}\text { ZJ04-C2-3- } \\
\text { MBN01 }\end{array}$ & $\begin{array}{l}\text { MB-N01, between } \\
\text { drives } 2 \text { and 3; } \\
\text { drawpoint drift } 04\end{array}$ & 60 & 580.1 & 532.0 & $92 \%$ & 381.0 & 1,989 & 917 & 2.17 \\
\hline $\begin{array}{l}\text { ZJ13-C1- } \\
\text { MBS01 }\end{array}$ & $\begin{array}{l}\text { MB-S01, drive 1; } \\
\text { drawpoint drift } 13\end{array}$ & 82 & 596.9 & 580.6 & $97 \%$ & 459.6 & 2,390 & 730 & 3.27 \\
\hline $\begin{array}{l}\text { ZJ06-C-1- } \\
\text { 2-MBN01 }\end{array}$ & $\begin{array}{l}\text { MB-N01, between } \\
\text { drives } 1 \text { and 2; } \\
\text { drawpoint drift } 06\end{array}$ & 60 & 580.1 & 539.7 & $93 \%$ & 389.7 & 2,025 & 917 & 2.21 \\
\hline $\begin{array}{l}\text { ZJ12-C-1-2- } \\
\text { MBS01 }\end{array}$ & $\begin{array}{l}\text { MB-S01, between } \\
\text { drives } 1 \text { and 2; } \\
\text { drawpoint drift } 12\end{array}$ & 76 & 452.9 & $S / 1$ & - & $S / I$ & $S / I$ & - & - \\
\hline
\end{tabular}

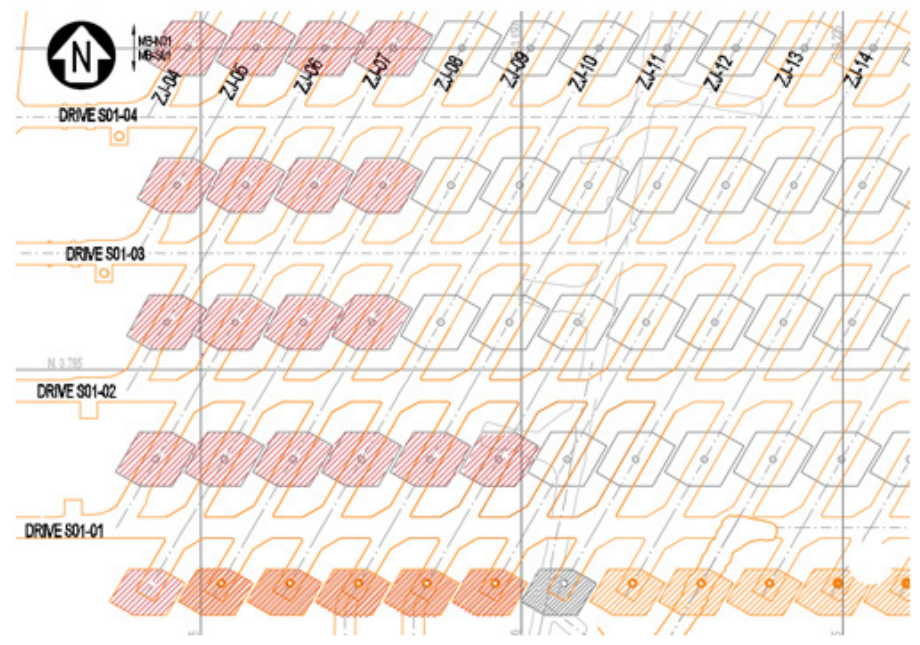


The total length of drillholes was categorized as short in $40 \%$ of the cases. When this occurred, it was possible, in some cases, to reach a greater real length. In those cases, in which it was not possible, an attempt was made to over-drill on nearby holes (12\% of the total holes were over-drilled) or to drill auxiliary holes, with the aim of maintaining the planned amount of explosive.

\subsection{Standard design results}

The results of the drawbells blasted were based on the resulting fragmentation and analysis made by scanning the surfaces generated.

\subsubsection{Fragmentation results}

The results of fragmentation of 4 drawbells were recorded and summarized in Table 5 .

Table 5 Fragmentation of drawbells in MCHS

\begin{tabular}{|c|c|c|c|}
\hline Drawbell & Location & $\begin{array}{c}\text { Medium size } \\
(\mathbf{m m})\end{array}$ & $\begin{array}{c}\text { Maximum size } \\
(\mathbf{m m})\end{array}$ \\
\hline $\begin{array}{c}\text { ZJ08S-C1 -MBS01- } \\
001\end{array}$ & MB-S01, drive 1; drawpoint drift 08 & 133 & 326 \\
\hline $\begin{array}{c}\text { ZJ07-C1-2- } \\
\text { MBS01-002 }\end{array}$ & $\begin{array}{c}\text { MB-S01, between drives 1 and 2; } \\
\text { drawpoint drift 07 }\end{array}$ & $145-225$ & $444-677$ \\
\hline $\begin{array}{c}\text { ZJ09S-C1-MBS01- } \\
003\end{array}$ & MB-S01, drive 1; drawpoint drift 09 & 128 & 858 \\
\hline $\begin{array}{c}\text { ZJ06-C2-3- } \\
\text { MBS01-004 }\end{array}$ & MB-S01, drives 2 and 3; drawpoint drift 06 & 85 & 557 \\
\hline
\end{tabular}

Figure 12 shows the results of fragmentation of drawbells, where the reference size is $1 \mathrm{~m}$.
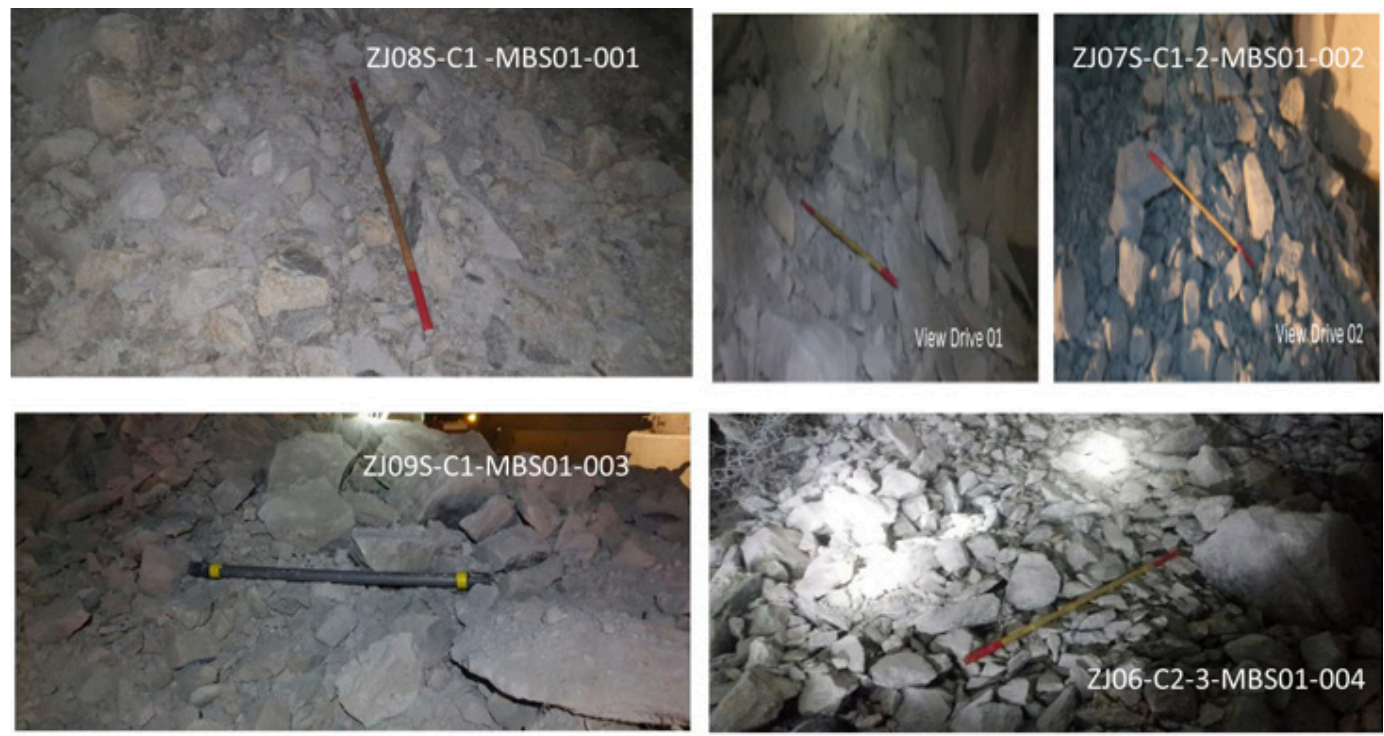

Figure 12 Fragmentation images in MCHS

The resulting fragmentation was a good size, which facilitated loading and transport. 


\subsubsection{Drawbell geometry results}

The results of the drawbells through 3D scans using I-Site were recorded at the Underground Chuquicamata Mine.

Scans show in most cases that drawbells comply well with the proposed design. Scans of drawbell 06 (between drives 2 and 3) and 07 (between drives 1 and 2) show that the blasting achieved good overall results, but with a slight tendency to sub-excavation of the upper limits of the drawbells (see Figure 13).
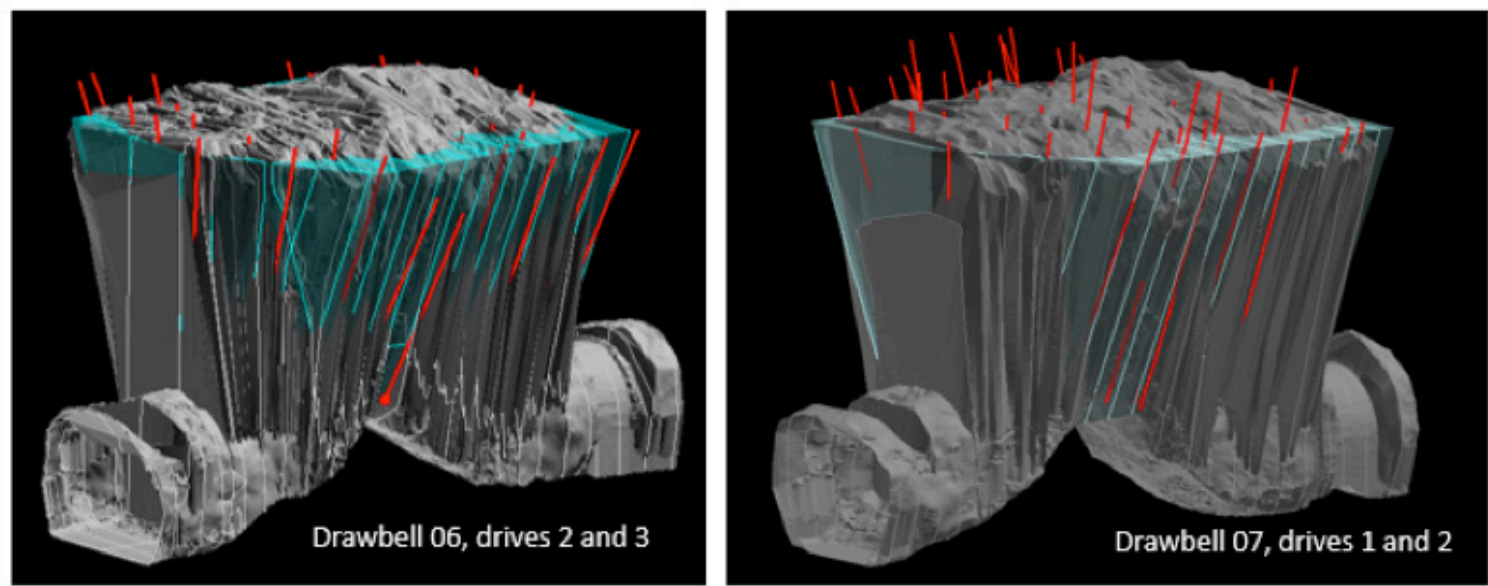

Figure 13 3D scan, drawbell 06 between drives 2 and 3 and drawbell 07 between drives 1 and 2, MB-S01

In the cases of half-drawbells, scans show there were problems in fulfilling the design, which was due to the difficulty to drill the farthest area from the production drift, as shown in Figure 14.

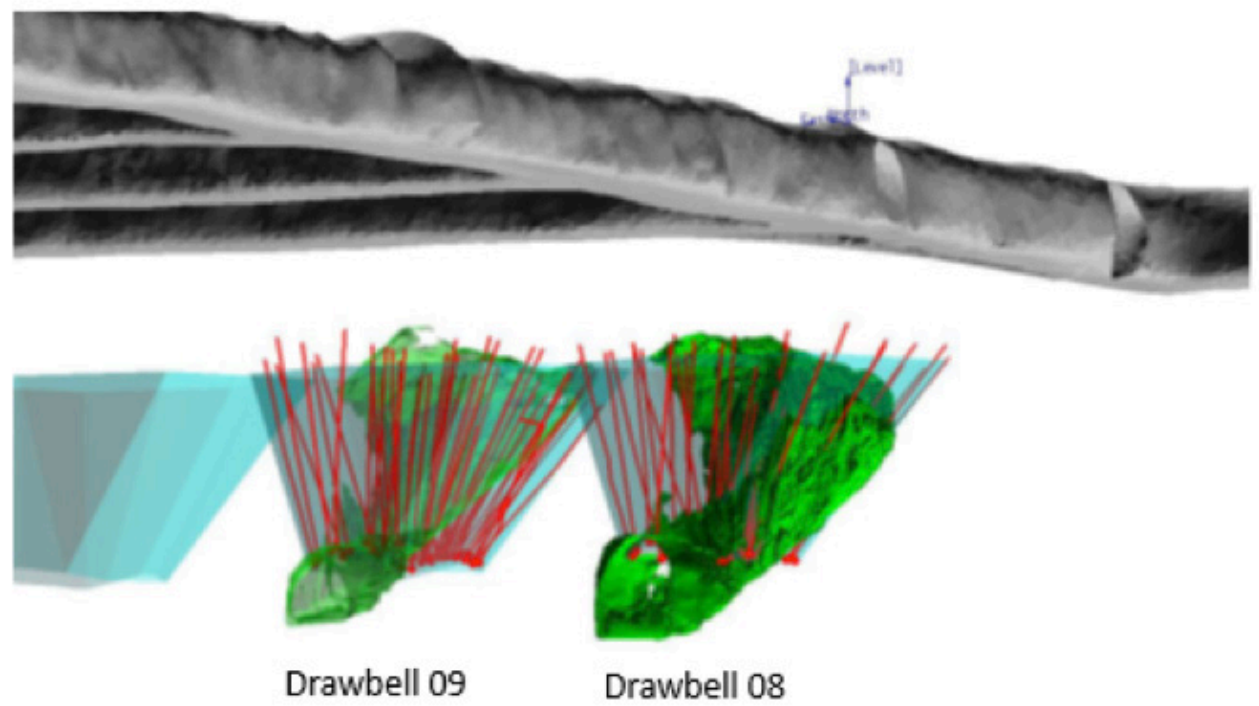

Figure 14 Scan of half-drawbells, drawbells 08 and 09, MB-S01

The scans of the height show generally good results in terms of complying with the design. The exception in these half-drawbells corresponded to the farthest areas of the drawpoint where the tendency to subexcavate, previously mentioned, was observed. 


\subsection{Unique features}

One notable feature of the Chuquicamata Underground Mine is an exploration ramp (F3S) that crosses between production and undercut levels on drive 1 between drawpoints drift 13 and 15. To manage this inconvenience, the design of drawbells 13 and 15 was changed to blast drawbells higher (from $9 \mathrm{~m}$ to $12.5 \mathrm{~m}$ ) as shown Figure 15. This implied not building a drawbell at drawpoint drift 14 (drawbell color gray in Figure 11).

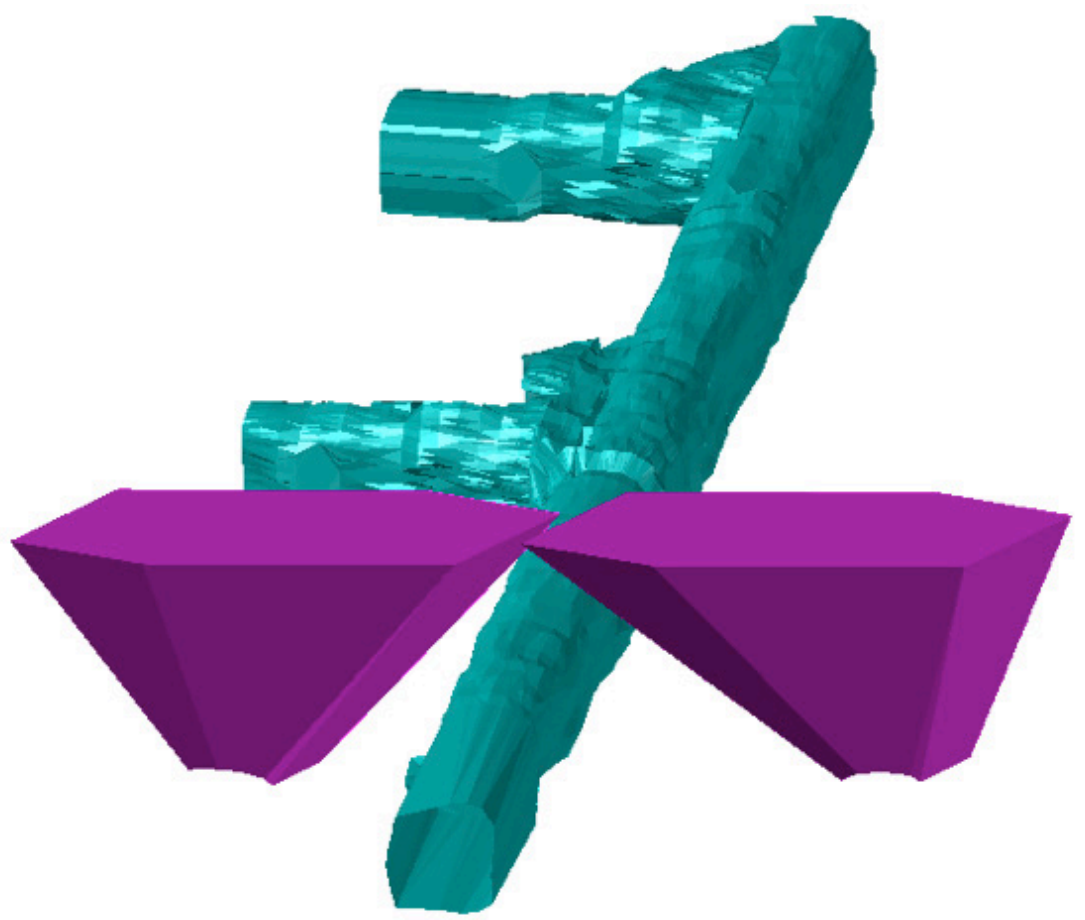

\section{Figure 15 Blasting higher drawbells in MCHS}

\section{Conclusions}

Until October 2019, 25 drawbells have been blasted at the MCHS. The lessons learned through this process are explained below:

- A guideline to blast drawbells requires a comprehensive study covering the stages of design, testing, implementation and analysis of results.

- The use of emulsion as an explosive agent for single-phase blasting has proved to be successful.

- The current drilling procedure allows to know the status of the boreholes, which leads to a more accurate blasting process.

- Implementation may need to address challenges, such as the presence of an exploration ramp at the undercut level, which requires changes in the design of some drawbells.

- The implementation of this design shows good results in the fragmentation generated and the final geometry of the drawbells.

- The implementation of drawbell blasting requires close collaboration between explosive providers (ENAEX) and the operation (Codelco). This interaction has proven to be key to achieving successful operation and meeting the goal of incorporating 8 or more drawbells per month as required by the project. 


\section{Acknowledgements}

The authors would like to thank Codelco Chile for allowing the publication of this article.

\section{References}

Alcaíno, J, Morales, D \& Paredes, P 2018, 'Implementation of emulsion in horizontal developments', PMCHS. UMINING 2018, II Ibero-American Congress in Underground Mining and Open Pit. Castro, R. and Herazo, Y. (eds). Santiago, Chile, 13-15 June 2018. pp. 438-451, in Spanish.

Altamirano, A 2014, 'Design of blasting in one phase- application to the Continuous Mining Project, Andina Mine', Master Thesis, University of Chile, Chile, in Spanish.

Araneda, O 2015, 'Challenges and Opportunities in open pit to underground transition at the Chuquicamata Underground Mine Project', Mine planning 2015 Conference, Keynote presentattion, Antofagasta, Chile, 8-10 July 2015.

Dunstan, G \& Popa, L 2012, 'Innovative Cave Establishment Practices at Ridgeways Deeps', Proceedings of MassMin 2012, Sudbury, Ontario, Canada.

Enaex 2018a, 'First Drawbell Test Blast 22 - MB_S02 - Drives 3 and 4', PMCHS Codelco VP.

Enaex 2018b, 'Tests of Blasting of Drawbell on 1 Phase. Operational Planning', August 2018.

Jofre, J, Yañez, P, \& Ferguson, G 2000, 'Evolution in Panel Caving undercutting and drawbell excavation, El Teniente Mine', in G Chitombo (ed.), Proceedings of MassMin 2000, Australian Institute of Mining and Metallurgy, Melbourne, Australia, pp. 249-260.

Lovitt, M \& Degay, B Jr 2003, 'Single shot drawbell blasting with Orica's i-kon® detonators at Freeport. In Explosives and Blasting Technique', CRC Press, pp. 240-247.

Music, A. \& San Martin, J 2010, 'Great volume Drawbells at El Teniente. Internal Report', CODELCO, Division El Teniente.

Paredes, P, Rodríguez, F, Castro, R, Morales, D, García, D 2019, 'Design and evaluation of one-phase drawbell excavation at the Chuquicamata Underground Mine', Journal of the Southern African Institute of Mining and Metallurgy, vol. 119, no. 12 , pp. 1061-1070.

Persson, P, Holmberg, R, Lee, J 1994, 'Stress Waves in Rock, and Fragmentation', In Rock blasting and explosive engineering, CRC, pp. 233-264.

Silveira, AC, Lovitt, M, \& Hewitt, T 2005, 'Off to a good start with Lift \#2: Drawbell extraction - Norhparkes', Proceedings Ninth Underground Operators' Conference, Perth, Australia, 2005, The Australasian Institute of Mining and Metallurgy, pp. 75-80. 